\title{
The Impact of Somatostatin Receptor-Directed PET/CT on the Management of Patients with Neuroendocrine Tumor: A Systematic Review and Meta-Analysis
}

\author{
Martin Barrio ${ }^{1}$, Johannes Czernin ${ }^{1}$, Stefano Fanti ${ }^{2}$, Valentina Ambrosini ${ }^{2}$, Ina Binse ${ }^{3}$, Lin Du ${ }^{4}$, Matthias Eiber ${ }^{1}$, \\ Ken Herrmann ${ }^{1,3}$, and Wolfgang P. Fendler ${ }^{1,5}$ \\ ${ }^{1}$ Department of Molecular and Medical Pharmacology, David Geffen School of Medicine at UCLA, Los Angeles, California; ${ }^{2}$ Nuclear \\ Medicine Unit, University of Bologna, S. Orsola Hospital Bologna, Bologna, Italy; ${ }^{3}$ Department of Nuclear Medicine, University \\ Hospital Essen, Essen, Germany; ${ }^{4}$ Department of Biostatistics, David Geffen School of Medicine at UCLA, Los Angeles, California; \\ and ${ }^{5}$ Department of Nuclear Medicine, Ludwig-Maximilians-University of Munich, Munich, Germany
}

\begin{abstract}
Somatostatin receptor (SSTR) imaging is widely used for guiding the management of neuroendocrine tumor (NET) patients. ${ }^{68} \mathrm{Ga}-\mathrm{DOTATATE}$ approval by the U.S. Food and Drug Administration has triggered widespread clinical interest in SSTR PET/CT throughout the United States. Here, we performed a systematic review and meta-analysis to evaluate the impact of SSTR PET/CT on the management of patients with NETs. Methods: A comprehensive literature search was performed using The National Center for Biotechnology Information PubMed online database, applying the following key words: "management" AND "PET" AND "neuroendocrine". Fourteen of 190 studies were deemed suitable based on the following inclusion criteria: original research, cohort study, number of patients 10 or more, and reported change in management after SSTR PET/CT. Change in management across studies was determined by a random-effects model. Results: A total of 1,561 patients were included. Overall, change in management occurred in $44 \%$ (range, $16 \%-71 \%$ ) of NET patients after SSTR PET/CT. In 4 of 14 studies, SSTR PET/CT was performed after an ${ }^{111}$ In-Octreotide scan. In this subgroup, additional information by SSTR PET/CT led to a change in management in $39 \%$ (range, $16 \%-71 \%$ ) of patients. Seven of 14 studies differentiated between inter- and intramodality changes, with most changes being intermodality (77\%; intramodality, $23 \%$ ). Conclusion: The management was changed in more than one third of patients undergoing SSTR PET/CT even when performed after an ${ }^{111} \mathrm{In}$-Octreotide scan. Intermodality changes were 3 times more likely than intramodality changes, underlining the clinical impact of SSTR PET/CT.
\end{abstract}

Key Words: neuroendocrine; oncology; Gl; peptides; PET/CT; DOTATATE; DOTATOC; SSTR; management

J Nucl Med 2017; 58:756-761

DOI: 10.2967/jnumed.116.185587

Received Oct. 14, 2016; revision accepted Dec. 5, 2016.

For correspondence or reprints contact: Ken Herrmann, University of California at Los Angeles, Ahmanson Translational Imaging Division, 10833 Le Conte Ave., 200 Medical Plaza, Ste. B114-61, Los Angeles, CA 90095-7370.

E-mail: kherrmann@mednet.ucla.edu

Guest Editor: Michael M. Graham, University of lowa.

Published online Jan. 12, 2017.

COPYRIGHT (C) 2017 by the Society of Nuclear Medicine and Molecular Imaging.
$\mathbf{N}$ cells most frequently from the bronchopulmonary or gastrointestinal system (1). Each year an estimated 8,000 individuals are newly diagnosed with NET in the United States, and the annual incidence has increased 5-fold since 1973 (2).

Accurate initial evaluation and detection of recurrence is paramount for all malignancies, including NETs. Traditionally, the diagnostic workup involved morphologic imaging such CT, ultrasonography, or MRI. These resulted in limited detection rates due to a variety of factors such as small size, variable location, and low metabolic rates (3). It was later discovered that well-differentiated NETs express high levels of somatostatin receptor (SSTR), specifically subtype 2 (4). Therefore, in addition to conventional imaging, SSTR-targeted imaging could be applied to detect and functionally characterize NETs.

SSTR scintigraphy using ${ }^{111}$ In-DTPA-penteoctreotide (Octreoscan) was one of the first tracers developed to functionally image NETs. This probe binds with high affinity to SSTR, specifically subtypes 2 and 5 (5). Although considered a breakthrough at the time, Octreoscan suffered from limited image quality, limited spatial resolution, and prolonged imaging protocols (6). Over the past 2 decades, several chelator-conjugated somatostatin analogs were developed, among these DOTATATE, DOTANOC, and DOTATOC. These short amino acid-chelator conjugates demonstrated an affinity for SSTR superior to that of Octreoscan $(7,8)$. DOTA agents can be labeled with ${ }^{68} \mathrm{Ga}$, a generator-eluted positron emitter that enables PET imaging and thus provides improved image quality and spatial resolution.

Several studies attest to the superior performance of ${ }^{68} \mathrm{Ga}$ labeled SSTR PET compared with Octreoscan (9-12). This was recognized recently by the U.S. Food and Drug Administration when it approved ${ }^{68} \mathrm{Ga}-\mathrm{DOTATATE}$ (NETSPOT $®$; Advanced Accelerator Applications) as an imaging agent for the detection of NETs.

Although the diagnostic performance of ${ }^{68} \mathrm{Ga}$-DOTATATE, ${ }^{68} \mathrm{Ga}$-DOTATOC, and ${ }^{68} \mathrm{Ga}$-DOTANOC has been reported in detail (11,13-17), the impact of SSTR PET/CT on patient management has not been reviewed systematically. The aim of this meta-analysis of published data was to determine the impact of SSTR PET/CT on the management of patients with NETs. 


\section{MATERIALS AND METHODS}

\section{Literature Search}

A systematic literature search was performed using The National Center for Biotechnology Information PubMed online database. The following key words were used for selection of studies: "neuroendocrine" AND "PET" AND "management". A full list of publications obtained with this search strategy is given in the supplemental material (available at http://jnm.snmjournals.org). Fourteen of 190 publications were deemed suitable based on the following inclusion criteria: original research, cohort study, reported change in management after somatostatin receptor imaging, and number of patients 10 or more.

\section{Data Extraction}

The following information was extracted from the 14 suitable studies: study type (prospective vs. retrospective), radioligand, sample size, change in management with type of management change (surgical vs. any) and intended versus implemented change, data acquisition method, responding entity, state of disease (primary staging vs. restaging), prior conventional imaging (if applicable), and response rates.

Additionally, treatment changes were extracted from selected studies if the prescan and postscan therapy recommendations were reported. Type of change was classified as inter- versus intramodality. An intermodality change was defined as change in the type of therapy (e.g., surgery to chemotherapy). An intramodality change was defined as change in dose/approach/technique within the suggested treatment modality (e.g., change in surgical strategy).

\section{Statistical Analysis}

Descriptive statistics such as mean and SD were used to summarize continuous variables, whereas count and percentage were used for categoric variables. The fixed-effects model approach may not provide proper inference for the dataset; so instead, we performed random-effects models for the overall impact on management for the 14 studies, as well as subgroup analysis with patients undergoing prior Octreoscan. The random-effects model estimates the magnitude of the heterogeneity, and assigns a greater variability to the estimate of overall change in management to

TABLE 1

Characteristics of Included Trials

\begin{tabular}{|c|c|c|c|c|c|c|c|c|c|c|c|}
\hline Study & Timeline & Radioligand & $\begin{array}{l}\text { No. of } \\
\text { patients }\end{array}$ & $\begin{array}{l}\text { Change in } \\
\text { management }\end{array}$ & $\begin{array}{l}\text { Change in } \\
\text { management } \\
\text { (any or } \\
\text { surgical only) }\end{array}$ & $\begin{array}{c}\text { Change in } \\
\text { intended or } \\
\text { implemented } \\
\text { management }\end{array}$ & $\begin{array}{c}\text { Response } \\
\text { rates }\end{array}$ & $\begin{array}{l}\text { Data acquisition } \\
\text { (review or } \\
\text { questionnaire) }\end{array}$ & $\begin{array}{l}\text { Responding } \\
\text { entity }\end{array}$ & $\begin{array}{c}\text { State of } \\
\text { disease } \\
\text { (primary } \\
\text { or any) }\end{array}$ & $\begin{array}{c}\text { Prior } \\
\text { conventional } \\
\text { imaging }^{\star}\end{array}$ \\
\hline $\begin{array}{l}\text { Frilling } \\
\text { et al. (27) }\end{array}$ & Retrospective & ${ }^{68} \mathrm{Ga}-\mathrm{DOTATOC}$ & 52 & $31(60 \%)$ & Any & Implemented & $100 \%$ & Review & $\begin{array}{l}\text { Independent } \\
\text { expert } \\
\text { commission }\end{array}$ & Any & Yes \\
\hline $\begin{array}{l}\text { Ambrosini } \\
\text { et al. (28) }\end{array}$ & Retrospective & ${ }^{68} \mathrm{Ga}-\mathrm{DOTANOC}$ & 90 & 32 (36\%) & Any & Implemented & $\mathrm{N} / \mathrm{A}$ & Questionnaire & $\begin{array}{l}\text { Referring } \\
\text { physician }\end{array}$ & Any & Yes \\
\hline Ruf et al. (29) & Retrospective & ${ }^{68} \mathrm{Ga}-\mathrm{DOTATOC}$ & 64 & 24 (38\%) & Any & Implemented & $97 \%$ & Review & $\begin{array}{l}\text { Independent } \\
\text { expert } \\
\text { commission }\end{array}$ & Any & Yes \\
\hline $\begin{array}{l}\text { Srirajaskanthan } \\
\text { et al. (21) }\end{array}$ & Retrospective & ${ }^{68} \mathrm{Ga}$-DOTATATE & 51 & $36(71 \%)$ & Any & Implemented & $16 \%$ & Review & $\begin{array}{l}\text { Independent } \\
\text { expert } \\
\text { commission }\end{array}$ & Any & Yes \\
\hline $\begin{array}{l}\text { Naswa } \\
\quad \text { et al. (23) }\end{array}$ & Prospective & ${ }^{68} \mathrm{Ga}-\mathrm{DOTANOC}$ & 109 & $21(19 \%)$ & Any & Implemented & $100 \%$ & Review & $\begin{array}{l}\text { Referring } \\
\text { physician }\end{array}$ & Any & Yes \\
\hline $\begin{array}{l}\text { Krausz } \\
\quad \text { et al. (12) }\end{array}$ & Prospective & ${ }^{68} \mathrm{Ga}-\mathrm{DOTANOC}$ & 19 & $3(16 \%)$ & Any & Intended & $100 \%$ & Review & $\begin{array}{l}\text { Referring } \\
\text { physician }\end{array}$ & Any & Yes \\
\hline $\begin{array}{l}\text { Froeling } \\
\text { et al. (31) }\end{array}$ & Retrospective & ${ }^{68} \mathrm{Ga}-\mathrm{DOTATOC}$ & 21 & $10(48 \%)$ & Any & Implemented & $\mathrm{N} / \mathrm{A}$ & Review & $\begin{array}{l}\text { Referring } \\
\text { physician }\end{array}$ & Any & No \\
\hline $\begin{array}{l}\text { Hofman } \\
\quad \text { et al. (32) }\end{array}$ & Retrospective & ${ }^{68} \mathrm{Ga}$-DOTATATE & 59 & $34(58 \%)$ & Any & Implemented & $\mathrm{N} / \mathrm{A}$ & Review & $\begin{array}{l}\text { Independent } \\
\text { expert } \\
\text { commission }\end{array}$ & Any & Yes \\
\hline $\begin{array}{r}\text { Has Simsek } \\
\text { et al. (33) }\end{array}$ & Prospective & ${ }^{68} \mathrm{Ga}$-DOTATATE & 27 & $16(59 \%)$ & Any & Intended & $100 \%$ & Review & $\begin{array}{l}\text { Independent } \\
\text { expert } \\
\text { commission }\end{array}$ & Any & Yes \\
\hline $\begin{array}{l}\text { Herrmann } \\
\quad \text { et al. (30) }\end{array}$ & Prospective & ${ }^{68} \mathrm{Ga}-\mathrm{DOTATATE}$ & 88 & $53(60 \%)$ & Any & Intended & $88 \%$ & Questionnaire & $\begin{array}{l}\text { Referring } \\
\text { physician }\end{array}$ & Any & Yes \\
\hline $\begin{array}{l}\text { Ilhan } \\
\text { et al. (34) }\end{array}$ & Retrospective & ${ }^{68} \mathrm{Ga}$-DOTATATE & 44 & $9(20 \%)$ & $\begin{array}{c}\text { Surgical } \\
\text { Only }\end{array}$ & Implemented & N/A & Review & $\begin{array}{l}\text { Independent } \\
\text { expert } \\
\text { commission }\end{array}$ & Primary & No \\
\hline $\begin{array}{l}\text { Sadowski } \\
\text { et al. (20) }\end{array}$ & Prospective & ${ }^{68} \mathrm{Ga}-\mathrm{DOTATATE}$ & 130 & $43(33 \%)$ & Any & Intended & $100 \%$ & Review & $\begin{array}{l}\text { Referring } \\
\text { physician }\end{array}$ & Any & Yes \\
\hline $\begin{array}{l}\text { Skoura } \\
\text { et al. }(19)^{\dagger}\end{array}$ & Retrospective & ${ }^{68} \mathrm{Ga}$-DOTATATE & $1,258^{\dagger}$ & $515^{\dagger}(41 \%)$ & Any & Implemented & $\mathrm{N} / \mathrm{A}$ & Review & $\begin{array}{l}\text { Independent } \\
\text { expert } \\
\text { commission }\end{array}$ & Any & Unknown \\
\hline Deppen et al. (22) & Retrospective & ${ }^{68} \mathrm{Ga}$-DOTATATE & 78 & $28(36 \%)$ & Any & Intended & $80 \%$ & Review & $\begin{array}{l}\text { Independent } \\
\text { expert } \\
\text { commission }\end{array}$ & Any & Yes \\
\hline
\end{tabular}

${ }^{*}$ Conventional imaging includes bone scanning, ultrasound, MRI, CT, Octreoscan, and ${ }^{18} \mathrm{~F}-\mathrm{FDG}$ PET/CT.

${ }^{\dagger}$ This study recorded total number of scans and was analyzed on a per-scan basis; number of patients in their study was 728 . 


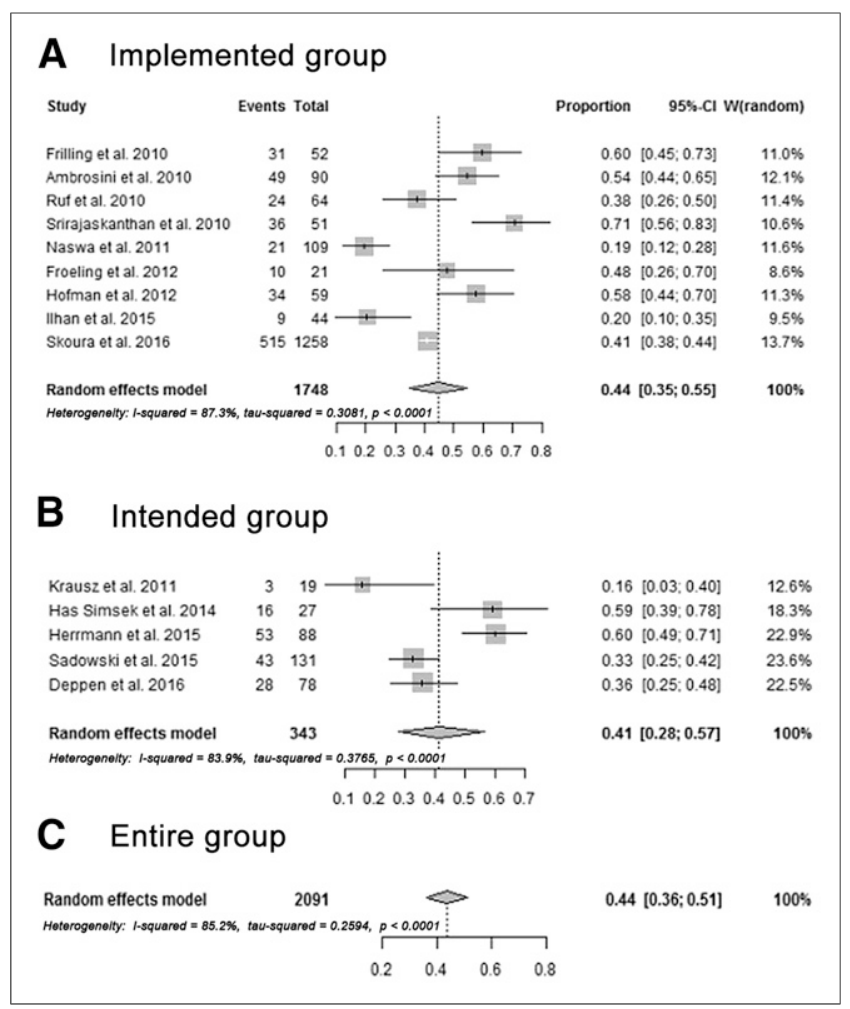

FIGURE 1. Analysis of change in management separated by implemented $(A)$ and intended $(B)$ changes and for all included studies (C).

account for this heterogeneity (18). Each study is weighted by the inverse of its variance (both for within-studies variance and betweenstudies variance). Consequently, individual study weights are more balanced, the impact of large trials decreases, and the confidence interval for the combined effect increases in width as compared with the fixed-effects model. Model diagnostics were performed to assess the forest plots with $95 \%$ confidence interval (CI). Tests for significance were 2-tailed, with a statistically significant $P$ value threshold of 0.05 . Statistical analyses were performed using $\mathrm{R}$ version 3.1.3.

\section{RESULTS}

\section{Study Characteristics}

On systematic review, 14 studies were included. Nine (64\%) were retrospective and $5(36 \%)$ were prospective. ${ }^{68} \mathrm{Ga}$-DOTATATE, ${ }^{68} \mathrm{Ga}$-DOTATOC, and ${ }^{68} \mathrm{Ga}$-DOTANOC were used in $8(57 \%)$, $3(21 \%)$, and $3(21 \%)$ studies, respectively. A total of 1,561 participants (737 men, 824 women; mean age, 54 y; age range, 15-
86 y) were included. The largest dataset, provided by Skoura et al., analyzed 728 patients retrospectively (19). The largest prospective study, by Sadowski et al. (20), included 130 patients. The remaining 12 studies included $53 \%$ of all patients (on average $4 \%$ per study). Characteristics of the included studies are presented in Table 1.

\section{Impact on Management}

The impact on management for the 14 studies is illustrated in Figures 1A-1C. PET/CT findings resulted in management changes in $44 \%$ of the patients $(95 \% \mathrm{CI}, 36 \%-51 \%$; range, $16 \%-71 \%$; Table 1; Fig. 1C). Studies on implemented management (Fig. $1 \mathrm{~A}$, implemented group) reported change in $44 \%$ (95\% CI, $35 \%-55 \%$; range, $19 \%-71 \%$ ), and studies on intended management (Fig. 1B, intended group) reported change in $41 \%$ (95\% CI, $28 \%-57 \%$; range, $16 \%-60 \%$ ) of patients.

Four studies on 278 patients performed SSTR PET/CT in addition to previous Octreoscan (Table 2) (12,20-22). In this subgroup, an average of $39 \%$ of patients (95\% CI, $0.22 \%-$ $0.59 \%$; range, $16 \%-71 \%$ ) experienced change in treatment strategy (Fig. 2). Figure 3 demonstrates ${ }^{68} \mathrm{Ga}$-DOTATATE PET/CT findings in a patient who underwent a previous Octreoscan (23).

Type of management change (inter- vs. intramodality) was documented in 7 of $14(50 \%)$ studies. Overall, intermodality changes $(77 \%)$ occurred more than 3 times more frequently than intramodality changes (23\%) (Fig. 4; Table 3 ).

\section{DISCUSSION}

This article provides a systematic analysis of the impact of SSTR PET/CT on the management in patients with NETs. Management changes were seen in $44 \%$ of all patients. No significant difference in the rate of management change was seen among reports of intended $(41 \%)$ versus implemented $(44 \%)$ management change. Management was also changed in 39\% of those patients who had undergone a previous Octreoscan. Finally, intermodality management changes occurred 3 times more frequently than intramodality changes.

The superior diagnostic performance of SSTR PET/CT as compared with Octreoscan has led to the recent U.S. Food and Drug Administration approval of ${ }^{68} \mathrm{Ga}$-DOTATATE as an imaging agent for NET. Three clinical studies were highlighted in the prescribing information of ${ }^{68} \mathrm{Ga}$-DOTATATE: 2 trials demonstrated high accuracy using histopathology or clinical follow-up for lesion verification $(24,25)$, and 1 trial demonstrated safety and significant change in management in a head-to-head comparison with Octreoscan (22).

Impact on management is a prerequisite for acceptance of diagnostic tests by physicians and insurance companies. Centers

TABLE 2

Change in Management in Patients with Prior Octreoscan

\begin{tabular}{llrr}
\hline \multicolumn{1}{c}{ Study } & Radioligand & No. of patients & Change in management \\
\hline Srirajaskanthan et al. (21) & ${ }^{68} \mathrm{Ga}-$ DOTATATE & 51 & $36(71 \%)$ \\
Krausz et al. (12) & ${ }^{68} \mathrm{Ga}-$ DOTANOC & 19 & $3(16 \%)$ \\
Sadowski et al. (20) & ${ }^{68} \mathrm{Ga}-$ DOTATATE & 130 & $43(33 \%)$ \\
Deppen et al. (22) & ${ }^{68} \mathrm{Ga}$-DOTATATE & 78 & $28(36 \%)$ \\
\hline
\end{tabular}




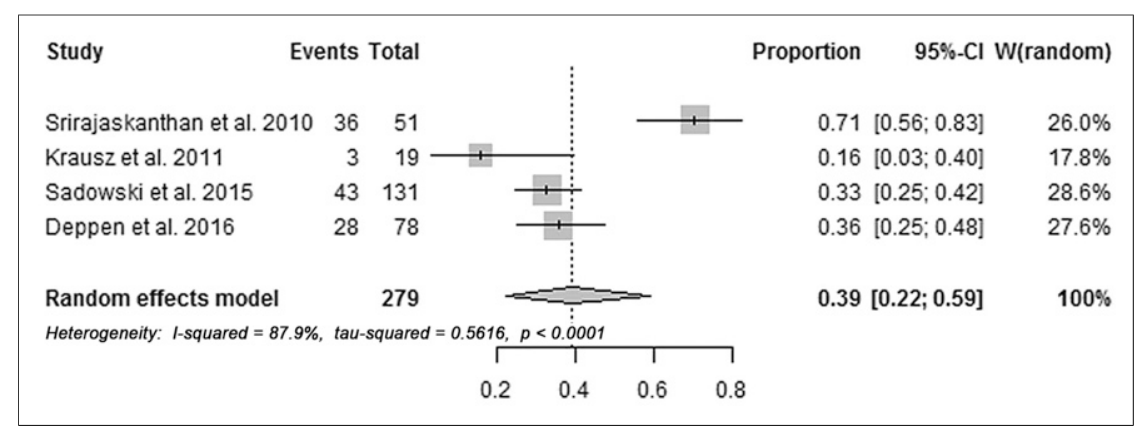

FIGURE 2. Subgroup analysis of patients who underwent Octreoscan before SSTR PET/CT.

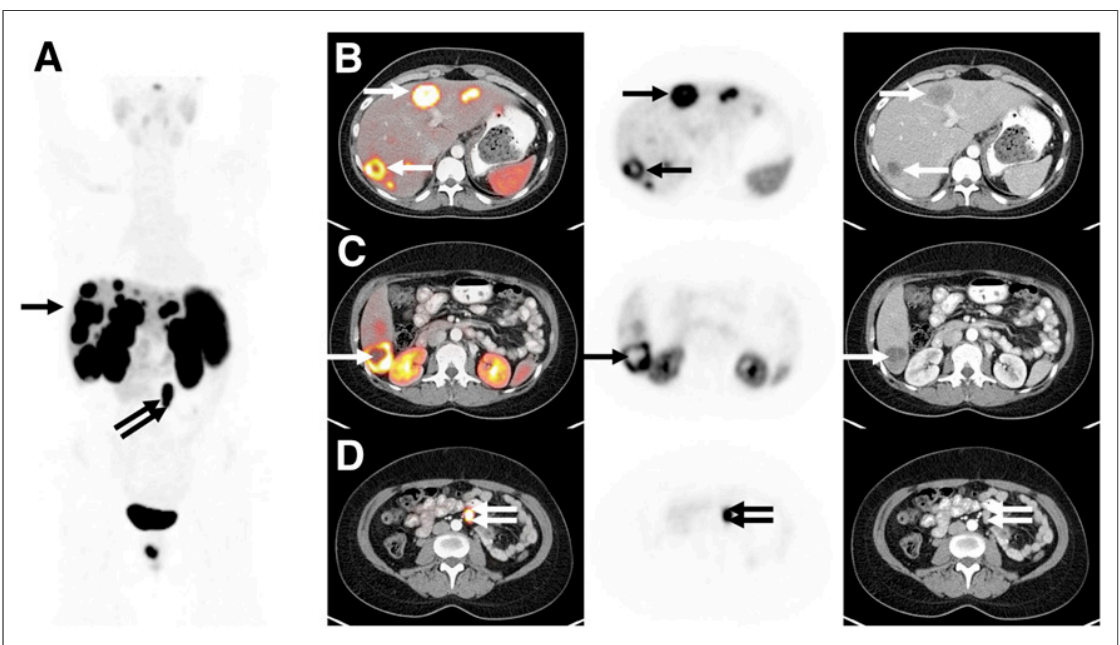

FIGURE 3. A 38-y-old female patient with metastatic NET of unknown primary. Octreoscan revealed SSTR-positive liver metastases. No extrahepatic disease was noted. Intended management was somatostatin-analog therapy. Maximum-intensity projection (A) and axial images of ${ }^{68} \mathrm{Ga}$-DOTATATE PET/CT performed 2 mo after Octreoscan are shown. PET/CT revealed numerous liver lesions (rows B and C) with intense tracer uptake (arrow). In addition, left mesenteric mass was discovered (row D, double arrow), which was later confirmed to be small bowel primary. Surgery for small bowel primary and initiation of somatostatin-analog therapy was implemented 2 mo after ${ }^{68} \mathrm{Ga}$-DOTATATE PET/CT scanning.

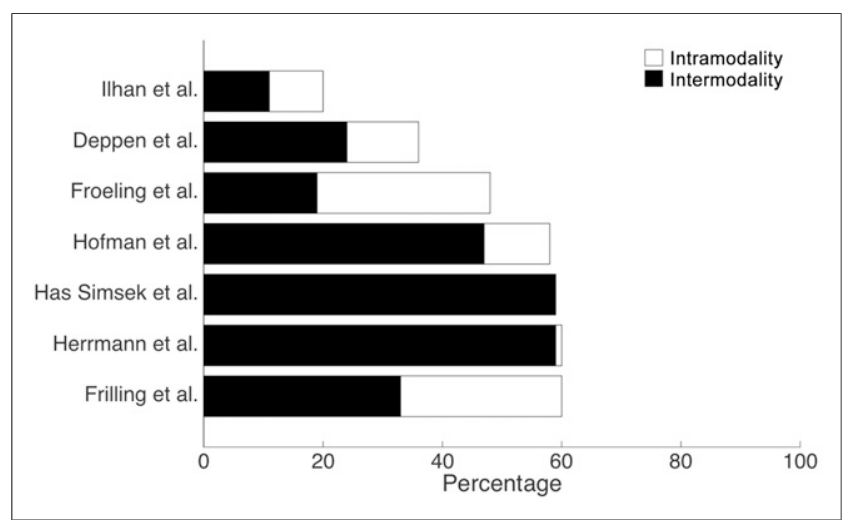

FIGURE 4. Type of change was differentiated in 7 of 14 (50\%) studies. Bars represent proportion of patients with any change in management, separated by subgroups with intermodality (black) vs. intramodality (white) change. for Medicare and Medicaid Services requested data on the impact of ${ }^{18} \mathrm{~F}-\mathrm{FDG}$ $\mathrm{PET} / \mathrm{CT}$ on clinical management to recommend reimbursement. This was evaluated in the National Oncologic PET Registry that enrolled thousands of patients and demonstrated intended management changes in around $40 \%$ of patients with a variety of cancers (26). Intermodality changes were 2 times more likely than intramodality changes (26). National Oncologic PET Registry findings led to wide coverage of ${ }^{18}$ F-FDG PET/CT by the Centers for Medicare and Medicaid Services. The degree of impact of ${ }^{18} \mathrm{~F}-\mathrm{FDG} \mathrm{PET} / \mathrm{CT}$ is comparable to that of SSTR PET/CT regarding overall management changes ( $>40 \%$ ); however, the rate of intermodality/ major changes was higher for SSTR PET/ CT (26).

The proportion of patients experiencing a change in management was similar in studies that reported intended $(41 \%)$ versus implemented $(44 \%)$ changes. This suggests that trials with intended endpoints do not suffer from low rates of implementation and underlines the validity of such endpoints. The additional value of SSTR PET/CT is robust and unaffected by previous SSTR scintigraphy. Thirty-nine percent of patients who had undergone a previous Octreoscan experienced treatment changes, highlighting the clinical impact of the more advanced PET/CT versus scintigraphy technology. Advantages also include the practicability of a 2-h PET/CT versus 2-d Octreoscan protocol, which was not analyzed by this meta-analysis.

Other limitations of this study should be noted: as with most meta-analyses, included articles were heterogeneous. Specifically, the definition of actual "change in management" varied from study to study. On the other hand, most of the included studies focused on implemented changes $(9 / 14,64 \%)$, and findings for the proportion of patients experiencing change in management were similar across all subgroups (average, 39\%-44\%). Skoura et al. (19) provided about half $(728 / 1,561,47 \%)$ of all the patients included in this study. Even though the change reported by Skoura et al. was well in range with results for the entire cohort, a random-effects model was used for analysis to avoid undue impact of this large trial.

\section{CONCLUSION}

Our systematic analysis demonstrates that PET/CT imaging using ${ }^{68} \mathrm{Ga}$-DOTATATE, ${ }^{68} \mathrm{Ga}$-DOTATOC, or ${ }^{68} \mathrm{Ga}$-DOTANOC is vital for patient management. Change occurred in similar magnitude when compared with the National Oncologic PET Registry multicenter trial resulting in ${ }^{18} \mathrm{~F}-\mathrm{FDG}$ PET/CT reimbursement. 
TABLE 3

Intermodality Versus Intramodality Management Change

\begin{tabular}{llcccc}
\hline \multicolumn{1}{c}{ Study } & Radioligand & No. of patients & $\begin{array}{c}\text { Overall change in } \\
\text { management }\end{array}$ & $\begin{array}{c}\text { Intermodality change* } \\
\text { Intramodality change* }\end{array}$ \\
\hline Frilling et al. (27) & ${ }^{68}$ Ga-DOTATOC & 52 & $31(60 \%)$ & $17(55 \%)$ & $14(45 \%)$ \\
\hline Froeling et al. (31) & ${ }^{68}$ Ga-DOTATOC & 21 & $10(48 \%)$ & $4(40 \%)$ & $6(60 \%)$ \\
\hline Hofman et al. (32) & ${ }^{68}$ Ga-DOTATATE & 59 & $34(58 \%)$ & $28(82 \%)$ & $6(18 \%)$ \\
\hline Has Simsek et al. (33) & ${ }^{68}$ Ga-DOTATATE & 27 & $16(59 \%)$ & $15(100 \%)^{\dagger}$ & $0(0 \%)$ \\
\hline Herrmann et al. (30) & ${ }^{68}$ Ga-DOTATATE & 88 & $53(60 \%)$ & $52(98 \%)$ & $1(2 \%)$ \\
\hline llhan et al. (34) & ${ }^{68}$ Ga-DOTATATE & 44 & $9(20 \%)$ & $5(55 \%)$ & $4(45 \%)$ \\
\hline Deppen et al. (22) & ${ }^{68}$ Ga-DOTATATE & 78 & $28(36 \%)$ & $19(68 \%)$ & $9(32 \%)$ \\
\hline
\end{tabular}

${ }^{*}$ Percentages are with respect to number of patients who had change in management.

${ }^{\dagger}$ Conflicting data: 15 patients are listed with a change in management, even though the article text reports 16.

SSTR PET allows sensitive tumor detection. On the basis of its accuracy, SSTR PET/CT is the standard of care in Europe, incorporated into clinical guidelines, and recently received approval in the United States for the evaluation of NET. SSTR radioligands further serve as predictive biomarkers to confirm target receptor expression and identify patients suitable for ${ }^{177}$ Lu-DOTATATE peptide receptor radionuclide therapy, currently under expanded access. This systematic analysis demonstrates that accuracy translates into change in clinical management, underlining the importance of SSTR PET/CT implementation into the routine care of NET patients.

\section{DISCLOSURE}

This study was partially funded by the U.S. Department of Energy, Office of Science Award DE-SC0012353. Wolfgang P. Fendler received a scholarship from the German Research Foundation (Deutsche Forschungsgemeinschaft, DFG). Ken Herrmann and Wolfgang P. Fendler are consultants of Ipsen and have a research agreement with Advanced Accelerator Applications (AAA). No other potential conflict of interest relevant to this article was reported.

\section{REFERENCES}

1. Hauso O, Gustafsson BI, Kidd M, et al. Neuroendocrine tumor epidemiology: contrasting Norway and North America. Cancer. 2008;113:2655-2664.

2. Yao JC, Hassan M, Phan A, et al. One hundred years after "carcinoid": epidemiology of and prognostic factors for neuroendocrine tumors in 35,825 cases in the United States. J Clin Oncol. 2008;26:3063-3072.

3. Shi W, Johnston CF, Buchanan KD, et al. Localization of neuroendocrine tumours with [ $\left.{ }^{111} \mathrm{In}\right]$ DTPA-octreotide scintigraphy (Octreoscan): a comparative study with CT and MR imaging. QJM. 1998;91:295-301.

4. Papotti M, Bongiovanni M, Volante M, et al. Expression of somatostatin receptor types 1-5 in 81 cases of gastrointestinal and pancreatic endocrine tumors: a correlative immunohistochemical and reverse-transcriptase polymerase chain reaction analysis. Virchows Arch. 2002;440:461-475.

5. Oberg K. Management of neuroendocrine tumours. Ann Oncol. 2004;15(suppl 4):iv293-iv298.

6. Maxwell JE, Sherman SK, Menda Y, Wang D, O'Dorisio TM, Howe JR. Limitations of somatostatin scintigraphy in primary small bowel neuroendocrine tumors. J Surg Res. 2014;190:548-553.

7. Reubi JC, Schar JC, Waser B, et al. Affinity profiles for human somatostatin receptor subtypes SST1-SST5 of somatostatin radiotracers selected for scintigraphic and radiotherapeutic use. Eur J Nucl Med. 2000;27:273-282.
8. Wild D, Macke HR, Waser B, et al. ${ }^{68} \mathrm{Ga}$-DOTANOC: a first compound for PET imaging with high affinity for somatostatin receptor subtypes 2 and 5. Eur J Nucl Med Mol Imaging. 2005;32:724.

9. Buchmann I, Henze M, Engelbrecht S, et al. Comparison of ${ }^{68} \mathrm{Ga}$-DOTATOC PET and ${ }^{111}$ In-DTPAOC (Octreoscan) SPECT in patients with neuroendocrine tumours. Eur J Nucl Med Mol Imaging. 2007;34:1617-1626.

10. Gabriel M, Decristoforo C, Kendler D, et al. ${ }^{68}$ Ga-DOTA-Tyr3-octreotide PET in neuroendocrine tumors: comparison with somatostatin receptor scintigraphy and CT. J Nucl Med. 2007;48:508-518.

11. Deppen SA, Blume J, Bobbey AJ, et al. ${ }^{68} \mathrm{Ga}$-DOTATATE compared with ${ }^{111} \mathrm{In}$ DTPA-Octreotide and conventional imaging for pulmonary and gastroenteropancreatic neuroendocrine tumors: a systematic review and meta-analysis. $\mathrm{J} \mathrm{Nucl}$ Med. 2016;57:872-878.

12. Krausz Y, Freedman N, Rubinstein R, et al. ${ }^{68}$ Ga-DOTA-NOC PET/CT imaging of neuroendocrine tumors: comparison with ${ }^{111} \mathrm{In}$-DTPA-octreotide (OctreoScan (R)). Mol Imaging Biol. 2011;13:583-593.

13. Ambrosini V, Campana D, Tomassetti P, Fanti S. ${ }^{68} \mathrm{Ga}$-labelled peptides for diagnosis of gastroenteropancreatic NET. Eur J Nucl Med Mol Imaging. 2012;39(suppl 1):S52-S60.

14. Treglia G, Castaldi P, Rindi G, Giordano A, Rufini V. Diagnostic performance of gallium-68 somatostatin receptor PET and PET/CT in patients with thoracic and gastroenteropancreatic neuroendocrine tumours: a meta-analysis. Endocrine. 2012;42:80-87.

15. Yang J, Kan Y, Ge BH, Yuan L, Li C, Zhao W. Diagnostic role of gallium-68 DOTATOC and gallium-68 DOTATATE PET in patients with neuroendocrine tumors: a meta-analysis. Acta Radiol. 2014;55:389-398.

16. Geijer H, Breimer LH. Somatostatin receptor PET/CT in neuroendocrine tumours: update on systematic review and meta-analysis. Eur J Nucl Med Mol Imaging. 2013;40:1770-1780.

17. Mojtahedi A, Thamake S, Tworowska I, Ranganathan D, Delpassand ES. The value of ${ }^{68} \mathrm{Ga}$-DOTATATE PET/CT in diagnosis and management of neuroendocrine tumors compared to current FDA approved imaging modalities: a review of literature. Am J Nucl Med Mol Imaging. 2014;4:426-434.

18. DerSimonian R, Laird N. Meta-analysis in clinical trials. Control Clin Trials. 1986;7:177-188.

19. Skoura E, Michopoulou S, Mohmaduvesh M, et al. The impact of ${ }^{68} \mathrm{Ga}$-DOTATATE PET/CT imaging on management of patients with neuroendocrine tumors: experience from a national referral center in the United Kingdom. $\mathrm{J}$ Nucl Med. 2016;57:34-40.

20. Sadowski SM, Neychev V, Millo C, et al. Prospective study of ${ }^{68}$ Ga-DOTATATE positron emission tomography/computed tomography for detecting gastroentero-pancreatic neuroendocrine tumors and unknown primary sites. J Clin Oncol. 2016;34:588-596.

21. Srirajaskanthan R, Kayani I, Quigley AM, Soh J, Caplin ME, Bomanji J. The role of ${ }^{68} \mathrm{Ga}$-DOTATATE PET in patients with neuroendocrine tumors and negative or equivocal findings on ${ }^{111} \mathrm{In}-\mathrm{DTPA}$-octreotide scintigraphy. $\mathrm{J} \mathrm{Nucl} \mathrm{Med}$. 2010;51:875-882.

22. Deppen SA, Liu E, Blume JD, et al. Safety and efficacy of ${ }^{68}$ Ga-DOTATATE PET/CT for diagnosis, staging, and treatment management of neuroendocrine tumors. J Nucl Med. 2016;57:708-714. 
23. Naswa N, Sharma P, Kumar A, et al. Gallium-68-DOTA-NOC PET/CT of patients with gastroenteropancreatic neuroendocrine tumors: a prospective singlecenter study. AJR. 2011;197:1221-1228.

24. Haug AR, Cindea-Drimus R, Auernhammer CJ, et al. Neuroendocrine tumor recurrence: diagnosis with ${ }^{68} \mathrm{Ga}$-DOTATATE PET/CT. Radiology. 2014;270:517525.

25. Haug AR, Cindea-Drimus R, Auernhammer CJ, et al. The role of ${ }^{68} \mathrm{Ga}$-DOTATATE PET/CT in suspected neuroendocrine tumors. J Nucl Med. 2012;53:16861692.

26. Hillner BE, Siegel BA, Liu D, et al. Impact of positron emission tomography/ computed tomography and positron emission tomography (PET) alone on expected management of patients with cancer: initial results from the National Oncologic PET Registry. J Clin Oncol. 2008;26:2155-2161.

27. Frilling A, Sotiropoulos GC, Radtke A, et al. The impact of ${ }^{68} \mathrm{Ga}$-DOTATOC positron emission tomography/computed tomography on the multimodal management of patients with neuroendocrine tumors. Ann Surg. 2010;252:850856.

28. Ambrosini V, Campana D, Bodei L, et al. ${ }^{68} \mathrm{Ga}$-DOTANOC PET/CT clinical impact in patients with neuroendocrine tumors. J Nucl Med. 2010;51:669673.
29. Ruf J, Heuck F, Schiefer J, et al. Impact of multiphase ${ }^{68} \mathrm{Ga}$-DOTATOC-PET/CT on therapy management in patients with neuroendocrine tumors. Neuroendocrinology. 2010;91:101-109.

30. Herrmann K, Czernin J, Wolin EM, et al. Impact of ${ }^{68}$ Ga-DOTATATE PET/CT on the management of neuroendocrine tumors: the referring physician's perspective. J Nucl Med. 2015;56:70-75.

31. Froeling V, Elgeti F, Maurer MH, et al. Impact of Ga-68 DOTATOC PET/CT on the diagnosis and treatment of patients with multiple endocrine neoplasia. Ann Nucl Med. 2012;26:738-743.

32. Hofman MS, Kong G, Neels OC, Eu P, Hong E, Hicks RJ. High management impact of Ga-68 DOTATATE (GaTate) PET/CT for imaging neuroendocrine and other somatostatin expressing tumours. J Med Imaging Radiat Oncol. 2012;56: 40-47.

33. Has Simsek D, Kuyumcu S, Turkmen C, et al. Can complementary ${ }^{68}$ Ga-DOTATATE and ${ }^{18} \mathrm{~F}$-FDG PET/CT establish the missing link between histopathology and therapeutic approach in gastroenteropancreatic neuroendocrine tumors? $\mathrm{J} \mathrm{Nucl} \mathrm{Med}$. 2014;55:1811-1817.

34. Ilhan H, Fendler WP, Cyran CC, et al. Impact of ${ }^{68} \mathrm{Ga}$-DOTATATE PET/CT on the surgical management of primary neuroendocrine tumors of the pancreas or ileum. Ann Surg Oncol. 2015;22:164-171. 